MAREK SOKOŁOWSKI

Uniwersytet Warmińsko-Mazurski

$w$ Olsztynie

\title{
EXIT FROM SILENCE. THE CULTURAL, EDUCATIONAL, AND THERAPEUTIC ROLES OF THE OLSZTYN MIME ENSEMBLE
}

\begin{abstract}
Sokołowski Marek, Exit from Silence. The Cultural, Educational, and Therapeutic Roles of the Olsztyn Mime Ensemble [Wyjście z ciszy. Rola kulturalna, edukacyjna i terapeutyczna Olsztyńskiej Pantomimy Głuchych]. Studia Edukacyjne nr 50, 2018, Poznań 2018, pp. 229-239. Adam Mickiewicz University Press. ISSN 1233-6688. DOI: 10.14746/ se.2018.50.15
\end{abstract}

The article recalls the role played by the Olsztyn Mime Ensamble in the culture of the region of Warmia and Mazury and Poland. The Ensamble gained their artistic rank thanks to the theater director, professor Bohdan Głuszczak (1936-2016).

Key words: amateur theatre, Olsztyn Mime Ensamble, deaf, silent actors, Bohdan Głuszczak

\section{Prologue. The Amateur Theatre of the Deaf-Mute}

In the 1950s, at the Provincial House of Culture (Wojewódzki Dom Kultury) in Olsztyn, an amateur theatre functioned; one of its members was Mirosław Ostaszkiewicz. ${ }^{1}$ At the end of 1956 his deaf brother Tadeusz, who had been fascinated by theatre for a long time, began to accompany him to rehearsals. Later, he would bring along his deaf friends from the disabled people's cooperative.

After a few months they showed three mime humoresques in sign language in the sitting room of the Olsztyn branch of the Polish Association of

110 lat Olsztyńskiej Pantomimy Gtuchych. Mówiący gestem [10 years of the Olsztyn Mime Ensemble of the Deaf. Speaking by Gesture] (catalogue), Department of Culture of the Presidium of the Provincial National Council in Olsztyn, Olsztyn 1967, p. 7. 
the Deaf. ${ }^{2}$ Another couple of months passed before they ventured to perform at the Provincial House of Culture. After the presentation, director Władysław Jarczewski offered them mentoring and space for rehearsals. In this way the deaf people's amateur theatre company became an ensemble of the Provincial House of Culture. They called themselves the Amateur Theatre of the DeafMute at the WDK in Olsztyn.

The first production by the Amateur Theatre of the Deaf-Mute was opened in January 1958. A one-act comedy by Aleksander Fredro, "I Am a Killer", was directed by Witold Dowgird, artistic director of the Provincial House of Culture. The audience was composed of the deaf, their families, and members of other amateur ensembles at the WDK.

In mid-November 1958 the deaf actors put their skills in competition with those of similar companies during the fourth National Presentation of Artistic Ensembles of the Deaf, held in Olsztyn. The contest was organised by the Olsztyn branch of the Polish Association of the Deaf, and the Provincial House of Culture. Two companies applied: one from Wrockaw and one from Warsaw; the hosts, with "I Am a Killer", was the third one. The Olsztyn ensemble took last place, and the jury and the press noted that they had acted very well, yet the sign language had made it difficult to understand their play. The verdict of the jury underlined the social and educational value of the project. Not a single word was dedicated to the artistic quality of the performance.

In August 1959 Bohdan Głuszczak, then a fourth-year student of the Łódź State Higher School of Film and Theatre (shortly before his studies, he had become a theatre instructor at the WDK), began working with deaf actors. When taking over the artistic direction of the company he assumed that its productions could not be staged in sign language, but in a universal one, understandable to everybody, as was pantomime, the stage art discipline closest to the deaf actors' natural way of being. ${ }^{3}$

As pantomime, we define a silent stage performance in which the content is communicated through gestures, movements, and sometimes also facial expression. It was not born as an independent art; its elements were contained in dance and dramatic theatre. The beginnings of mime date back to Etruscan dances and fescennine verses, i.e. Italic poems or folk songs in the form of a satirical dialogue of young people, performed during weddings and harvest festivals $\left(6^{\text {th }}-4^{\text {th }}\right.$ century BC), Greek dance theatre, and Greek and Roman mime. In ancient Greece, it was a plebeian, "careless and flippant" spectacle ${ }^{4}$,

\footnotetext{
${ }^{2}$ Ibidem, s. 7.

${ }^{3}$ Bohdan Głuszczak's statement in an interview with Tadeusz Prusiński - TP’s private archives.

${ }^{4}$ Zbigniew Raszewski - preface to the book by Janina Hera, Z dziejów pantomimy, czyli pałac zaczarowany [From the History of Pantomime, or the Enchanted Palace], Państwowy Instytut Wydawniczy, Warszawa 1975, p. XI.
} 
composed of acrobatic shows, demonstrations of agility, singing and dancing. The main source of modern mime is the commedia dell'arte, where gesture and facial expressions prevailed over words, thanks to which it was toured internationally, and was understandable to foreign audiences who did not know the language of the dialogues. ${ }^{5}$

Two types are distinguished in modern mime. The first one is a solo performance by a mime artist who, when expressing thoughts, ideas and phenomena, acts only through body movement and facial expression, identifying themselves not only with the character portrayed, but also with the elements of the world surrounding it. The other type is a dramaturgically developed staging in which a mime company performs accompanied by music, set, props, and very often costumes.

\section{From Therapeutic Experiment to International Stage Success}

When beginning his work with deaf amateur actors, the only thing Bohdan Głuszczak knew was that they could not hear. He agreed with the theory that theatrical work with them was supposed to be a form of therapy. But his intention was to go for more. He thought art should, first of all, dignify deaf people through the public creation of a work of stage art. It was also a chance to show deaf people as a community capable of creating and co-existing in the hearing people's world. ${ }^{6}$

The company, under the supervision of visual artist Zbigniew Borejsza, was then finishing preparations for the production "Sketches in Colour", a half-mime play composed of seven short stories: "The Park", "Abstract", "The Defeat of Pierrot", "Corrida", "The Tale of the Zodiacs" "Circus" and "The Ending in the Windows". The opening of the "Sketches" was held on the stage of WDK in Olsztyn on 19 September 1959. According to Bohdan Głuszczak, it was a spectacle created "in a painterly manner and with painterly imagination. That was already theatre of pure movement, in which the word proved unnecessary". ${ }^{\prime}$ It was also when the Amateur Theatre of the Deaf-Mute was renamed to become the Workers' Theatre "Olsztyn Mime Ensemble of the Deaf."

The first production by the Olsztyn Mime Ensemble of the Deaf, directed by Bohdan Głuszczak, was "The Umbrellas" (1960), inspired by Marcel Carné's famous film "Children of Paradise". It was followed by the mime play "The Carnival", prepared by the same director and artists. In 1962, both

\footnotetext{
${ }^{5}$ J. Hera, Z dziejów pantomimy.

${ }^{6}$ Bohdan Głuszczak's statement.

7 B. Głuszczak, Wszystko powiedzieć nic nie mówiąc [To Say It All While Saying Nothing], Scena, 1973, 4.
} 
works were united into a larger whole - "The Silent Comedians", which the Ensemble began to perform on a regular basis, although not very often, on the stage of the Provincial House of Culture. It was also shown in Poznań and Bydgoszcz, where it met with great interest.

At the beginning, the deaf mime artists' stage activity was treated as an interesting therapeutic experiment. However, from 1971 onwards, as the company began to win awards at international theatre festivals and competitions, they were no longer considered as a disabled people's company: after twelve years of hard work success finally came. The first show, after the première of which in 1971 the Olsztyn Mime Ensemble of the Deaf became famous in Poland and Europe, was "The Caprices", after drawings by Francisco Goya. ${ }^{8}$ The vision of the world as seen by a deaf painter, in which the Inquisition destroyed or distorted all ideational values, was extremely realistic and shocking. Deaf actor Tadeusz Ostaszkiewicz, just like Goya, was questioned by the Inquisition, experienced a lot of evil, including imprisonment and interrogation. He saw the horrors of war, hanged people, executions, war and he experienced contemporary disasters. For Ostaszkiewicz, Goya's drawings were not historical. Why not show then, on stage, the world observed by a deaf artist-actor who sees it in similarly horrific images?"

Such a message provided a foundation for "The Caprices" by the Olsztyn Mime Ensemble of the Deaf. The play was written, choreographed and directed by Bohdan Głuszczak, with music by Krzysztof Penderecki, on a set designed by Barbara and Eugeniusz Jankowski. The opening took place on 29 March 1971 at the Stefan Jaracz Theatre in Olsztyn.

"The Caprices" remained on stage for more than twenty years, to be performed for the last time in 1993. The play strengthened Bohdan Głuszczak's belief that further work should be supported, most of all, by painting. In the subsequent production, "Apocalypse", premiered on 26 May 1973 at the Jaracz Theatre in Olsztyn, inspired by the prophecy of St. John, Głuszczak created the script and choreography using Albrecht Dürer's engravings. ${ }^{10}$ He directed the play together with Jerzy Obłamski, using music by Krzysztof Penderecki and Henryk Mikołaj Górecki. The set was designed by Józef Zboromirski.

The two productions opened the door into Poland and the world for the Mime Ensemble. During numerous appearances in Europe they were often

${ }^{8}$ Francisco Goya y Lucientes, "Caprichos", cykl 80 rycin. Katalog wystawy z okazji 200-lecia urodzin artysty, 17 marzec - 17 kwiecień 1947 r. [Francisco Goya y Lucientes, "Caprichos," a series of 80 etchings. Catalogue of an exhibition on the 200th anniversary of the artist's birth, 17 March - 17 April 1947]. Muzeum Narodowe w Warszawie, 1947.

9 Bohdan Głuszczak's statement.

${ }^{10}$ J. Białostocki, Dürer, „Sztuka” Publishing House, Warszawa 1956. 
shown in combination, with "The Caprices" as the first part. Both also became a turning point in the history of the Olsztyn Mime Ensemble of the Deaf. That was when, after many years of following the model of the great mime artists: Marcel Marceau and Henryk Tomaszewski, the director and the company found their own means of expression. Głuszczak made his actors realize how to show and communicate emotions through rhythm. They no longer imitated anybody, and stopped using so-called pre-composed, sophisticated ("wheat meal") gestures. The form and "whole-grain taste" presented by the deaf mime artists from Olsztyn, i.e. certain severity, roughness, edginess of the stage movement, so different from the pre-composed gesture of Henryk Tomaszewski's Wrocław Mime Theatre - in which, moreover, Bohdan Głuszczak took part in several artistic internships - or from Marcel Marceau's mime art, became henceforth the hallmark of the Olsztyn Mime Ensemble. ${ }^{11}$

The following production, "The Polish Nativity Play", was prepared specially for the Polish community in the United States. The libretto was created and directed by Bohdan Głuszczak, using music by Ludomir Różycki and Karol Szymanowski; the set was designed by Józef Zboromirski. The première took place in New York on 12 August 1975, during the company's two-month US tour. ${ }^{12}$

The production following it - "Galatea" - opened on 4 March 1978, written and directed by Bohdan Głuszczak, with music by Czesław Niemen and set by Józef Zboromirski). It was a story about how the ideal loses its living form to become an object. ${ }^{13}$ The content of the play, composed of nine mime images, was an allegory going beyond the mythological anecdote. The company was significantly rejuvenated, which resulted in the critics' flattering opinions of the stage movement. One of them noted that the collective movement "symbolises instead of imitating, works through allusiveness, poetic metaphor, and beautiful visual composition". ${ }^{14}$ In Bohdan Głuszczak's opinion, the work did not attain, however, the degree of universalism of the "Caprices" and, especially, of "Apocalypse", their clarity, message, or dramaturgy. It never gained such popularity, either. ${ }^{15}$

Four years later the mime theatre from Olsztyn prepared "The Banquet", after Gombrowicz's works (with the script written by Bohdan Głuszczak, assisted in directing by Jacek Wierzbicki, music by Czesław Niemen and set design by Andrzej Markowicz), a play about power and its temptations.

11 Bohdan Głuszczak's statement.

12 Fred Berliner in the article Polish Mime Ensemble of the Deaf "Show Business" of 21 August 1975.

13 J. Niesiobędzki, Wkręgu "Galatei" [In the circle of "Galatea"] "Fakty”, 1978, 13.

14 I. Keller, Sztuka zatopiona w milczeniu [Art Plunged in Silence] "Teatr", 1978, 12.

15 Bohdan Głuszczak's statement. 
"The Banquet" was received with more aloofness than Bohdan Głuszczak's previous works. Yet the director thought that it was a very good play after all. ${ }^{16}$

In 1988 the Olsztyn Mime Ensemble showed the last production by this author: "The Polish Requiem", using music by Krzysztof Penderecki, set design by Andrzej Markowicz and masks by Sylwin Mydlak. Its world première took place in West Berlin at the end of August 1988, during the European Culture Days, to be opened two weeks later, on 10 September, on the stage of the Jaracz Theatre in Olsztyn. According to Bohdan Głuszczak, the production was a historical and poetic reflection on our thinking about history, about Polish martyrdom, its causes and consequences, a polemic with a certain variant of Christianity, the national messianism, the nineteenth-century thinking about Poland. ${ }^{17}$

A year later, Bohdan Głuszczak gave up the direction of the Mime Ensemble.

During the thirty years of his leadership, the Olsztyn mime company gained recognition and fame at home and abroad, winning numerous awards. Their most important achievements included first prizes at international deaf people's festivals in Warsaw and Brno, a prize at the International Biennial of Visual Theatres in Santa Cruz de Tenerife, the prestigious Deburau award for the whole artistic work (awarded in honour of the nineteenth-century mime master Jean-Gaspard Deburau), the Officer's Cross of the Order of Polonia Restituta, and an Award from the Minister of Foreign Affairs.

\section{Towards Integration}

After Bohdan Głuszczak's resignation the management and artistic direction were taken over by his former assistant Krzysztof Gedroyć. Two years later the company became independent in organisational and financial terms, passing from the structures of the Regional Cultural Centre (into which the Provincial House of Culture had been transformed) under the patronage of the "Olsztyn Mime Ensemble" Art Foundation. The foundation was established by a group of admirers of this kind of theatre.

The Olsztyn Workers' Mime Ensemble also changed its name to the New Olsztyn Mime Ensemble and adopted the formula of an integrated company, as the deaf actors' troupe was joined by hearing members. Director Euge-

\footnotetext{
${ }^{16}$ Ibidem.

17 B. Głuszczak, Wyjście z "polskiej otchłani” - rozmowa Bohdana Głuszczaka z Bohdanem Kurowskim [Getting Out of the "Polish abyss" - Bohdan Głuszczak's interview with Bohdan Kurowski], [in:] programme booklet for "The Polish Requiem", choreodram in 10 images, Stefan Jaracz Theatre, Olsztyn 1978.
} 
niusz Ozga staged here visual productions: "The Labyrinth" (1990) and "Babel" (1992). Successfully touring around Poland and Europe, they initiated the company's new style. ${ }^{18}$

By expanding its formula the Olsztyn Mime Ensemble also carried out stage work among disabled children and young people, becoming a theatrical integration centre which brought together several artistic groups. The so-called big Mime Theatre (a company of adult actors, directors Bohdan Głuszczak and Paweł Aigner) continued the tradition of classical mime art and its contemporary current, presenting, in 1997, "Mosquito Scream", directed by Paweł Aigner and, in 1998, "The Fool and the Actor", directed by Bohdan Głuszczak, with music by Czesław Niemen and set by Ryszard Kuzyszyn.

One of the groups of the so-called small Mime Theatre (children's groups) used the original authorial method created by director Maria Burniewicz, which combined the art of dance with live music on the foundation of eurhythmics. Until 2005, the children's theatre "Eurytmia" prepared six premières: "The Rainbow Bridge", "The Three Gifts", "Festive Days...", "Eurhythmic Dances", "Lead Me Little Path" and "The Enchanted Box".

Another group of youngsters developed the performances of the Little Shadow Theatre, led by Małgorzata Sienkiewicz and Ryszard Choiński. The group was composed mainly of children from Gypsy families and educationally disadvantaged ones, often with different dysfunctions.

The so-called small Mime Theatre also included a visual arts group, led by Julia Tarnowska and Ryszard Choiński. It was composed of children from dysfunctional families, poor Gypsy children and disabled ones. The activities involving them were meant as initial work, preparing for performances in the theatre group. They ended in June 1998 with an exhibition of the achievements of the arts group members (accompanied by a mini-catalogue).

In this way, under the auspices of the "Olsztyn Mime Ensemble" Art Foundation, a long-term comprehensive integration programme "To Be Together" was carried out until 2002. It was intended to help the disabled from the Olsztyn Mime Ensemble - and children's ensembles operating under the aegis of the foundation - adapt to the world of healthy people. The classes were led by a group of experienced theatre creators, directors and teachers. Using the expression of the disabled, triggered by theatre, dance and visual arts, they strived to integrate them with healthy people.

The headquarters of the Mime Ensemble at 15 Okopowa Street also hosted regular events called "Theatre Night", created by Krystyna Spikert. They allowed the debuting and presentation of young authors, gathering a large

${ }_{18}$ Program integracyjny "Być razem" ["To Be Together" integration programme], programme information booklet, Olsztyn 1996. 
number of young artists and volunteers around the theatre. Many of them later graduated from art colleges.

Shown for the first time in 1997, "Mosquito Scream" was the last première under the direction of Krzysztof Gedroyć, as he resigned from all functions and moved out of Olsztyn shortly afterwards. With "The Fool and the Actor", created a year later, the Mime Ensemble celebrated its fortieth anniversary. The play was also a benefit production in honour of Romuald Orzel, a deaf actor, who had been associated with the company for 35 years. The production included self-quotations from former plays. It spoke of the clash of "high" and "popular" art, but it was also an honest statement about art, buffoonery, authenticity in life and on stage, humility and pathos.

After the departure of Krzysztof Gedroyć, the Mime Ensemble was directed by Tadeusz Prusiński, substituted, from 31 October 1999 onwards, by Ryszard Choiński.

In the first half of 2002 the "Olsztyn Mime Ensemble" Art Foundation was dissolved. The only companies remaining out of those which had operated under its patronage were the gradually shrinking Olsztyn Mime Ensemble, and the "Eurytmia" theatre, gathering twenty children. In mid-2002 both were taken over by the Socio-Cultural Association "Gest", under the aegis of which they started to work in the space of the Centre for Education and Cultural Initiatives in Olsztyn (formerly the Regional Centre of Culture, ex-Provincial House of Culture). Wiesław Piesak, director, composer and graduate of a Swiss visual arts college, took care of the Olsztyn Mime Ensemble. In April 2005 he and the Olsztyn mime artists presented their second show (the first one being "Reading Beckett" in January 2003).

In its heyday the company had about 120 rehearsals per year, in addition to workshop camps, and touring productions in Poland and abroad. Altogether, the deaf mime artists often spent more time on stage and in the theatre than professional actors. They also frequently assisted the troupe of the Stefan Jaracz Theatre in Olsztyn - performing in "Hamlet" by W. Shakespeare (1968, 1983), "Medea" by Lucius Annaeus Seneca the Younger (1975), "One Flew Over the Cuckoo's Nest" by Dale Wasserman after Ken Kesey's novel (1979), "Equus" by Peter Schaeffer (1981), "Father Marek" by Juliusz Słowacki (1982), and "Kordian" by the same author (1984), "The Old Woman Broods" by Tadeusz Różewicz (1985) and "The Great Fryderyk" by Adolf Nowaczyński (1986).

The worldwide phenomenon of the Olsztyn Mime Ensemble also resulted from its pioneering therapeutic approach, which was Bohdan Głuszczak's undoubted merit. He was the first to begin rehabilitating the disabled through art, thus helping them find the meaning of life. He later travelled around the world, sharing his experiences at many universities. 
The Americans began dealing with this problem fifteen years after Głuszczak. In 1974, in the US, Jean Kennedy Smith (sister of the tragically deceased US president) founded the Very Special Arts organisation, helping the disabled cultivate art and educating teachers-artists to work with the disabled. ${ }^{19}$

Until mid-2005 the Olsztyn Mime prepared 20 premières (some of them being great theatre productions), and it became the subject of eight ballet films and documentaries. Its activity involved nearly 250 deaf people. In its 15 tours it performed in 21 countries (several times in some of them) in Europe, North America, Africa and Japan.

\section{Epilogue. "The Silent Comedians"}

At the end of 2015 the book "The Silent Comedians. A Study on Bohdan Głuszczak and the Olsztyn Mime Ensemble" was published. This book relates the story of the unique theatre and, at the same time, that of its creator, and the more than thirty creative years spent together by the director and actors. It is the story of the genesis of some great stagings which the company toured around the world, winning awards at festivals. ${ }^{20}$

The Olsztyn Mime Ensemble - the first theatre of the deaf - despite the fact of having been founded by Tadeusz Ostaszkiewicz, was the "child" of Bohdan Głuszczak, his authorial work. He wrote scripts for its productions, and choreographed and directed them. For hearing-impaired artists he was the spiritual and intellectual guide and, often, a father and a mother in their everyday life.

For a long time the activities of the deaf mime amateurs from Olsztyn were regarded as a therapeutic experiment. Success came after twelve years of hard work for Bohdan Głuszczak and his deaf actors, in 1971. It took the form of "The Caprices", basoed on the paintings and drawings by the Spanish artist Francisco Goya; the production was presented on stage for more than twenty years. After that, the Olsztyn mime theatre was no longer regarded as a disabled people's company. They were recognised as artists denoted with a capitalised name. ${ }^{21}$

${ }^{19}$ Very Special Arts Foundation - organisation with a global reach, part of The John F. Kennedy Center for the Performing Arts Education Office (J.F. Kennedy Institute for Artistic and Educational Achievements) in Washington.

${ }_{20}$ T. Prusiński, Milczący komedianci. Rzecz o Bohdanie Głuszczaku i Pantomimie Olsztyńskiej [The Silent Comedians. A Study on Bohdan Głuszczak and the Olsztyn Mime Ensemble], Olsztyn 2015, p. 5 .

21 Ibidem. 
Also, their following mime productions: "Apocalypse" based on the revelations of St. John the Evangelist and engravings by Albrecht Dürer, "The Polish Nativity Play", based on old Polish ceremonial plays, "Galatea" - the story of Pygmalion and his oeuvre, and the not less theatrical and expressive "Banquet" and "Polish Requiem" also went down in the history of theatre and not only Polish theatre.

The productions of the Olsztyn Mime Ensemble were inspired by mythology and the Bible, as well as by music, painting and sculpture. They used compositions by Krzysztof Penderecki, Henryk Mikołaj Górecki, Ludomir Różycki, Karol Szymanowski, and Czesław Niemen.

Several films were also created about the Olsztyn Mime Ensemble; most of them are recordings of its performances. ${ }^{22}$

Deaf mime amateurs also performed in professional theatre productions, most frequently at the Olsztyn Stefan Jaracz Theatre. The first play involving a deaf actor was opened on a professional stage on 3 February 1968, in Olsztyn ("Hamlet" by Shakespeare). They also played in Goethe's "Faust" directed by Grzegorz Królikiewicz for the Television Theatre, where they appeared in the famous sequence of "Walpurgis Night". At the Television Theatre Festival in Varna, Bulgaria, the prize was not awarded to "Faust" but only to its fragment, "Walpurgis Night".

Besides the Olsztyn Mime Ensemble, director Bohdan Głuszczak co-authored nearly a hundred plays for twenty-two other stages. In many of them he made use of the experience taken from the company he led, as well as from mask theatre. On the other hand, he enriched the Mime Ensemble with means of expression observed on other stages, in the work of outstanding directors and professional actors (including Jerzy Grzegorzewski, Jerzy Jarocki, Stanisław Hebanowski, Adam Hanuszkiewicz, Gustaw Holoubek, Piotr Fronczewski, and Marek Walczewski).

In the 90s, the company of deaf mime artists changed. Many of them left, to be substituted with hearing people, in connection with the broadening of the company's formula. The managers and stage directors changed, while Bohdan Głuszczak devoted himself to teaching. In addition to many years of teaching mask theatre and stage movement at the Department of Puppetry in Białystok (belonging to the Theatre Academy in Warsaw), he gave classes, from 1992 onwards, to students of the Higher School of Pedagogy and, after the founding of the University of Warmia and Mazury in Olsztyn, he continued in that institution until 2008.

For its last few years, the Olsztyn Mime Ensemble existed as an amateur theatre group under the patronage of the Centre for Education and Cultural

${ }^{22}$ Ibidem, p. 223; M. Sokołowski, Speaking by Gesture, "Film”, 1988, 4, p. 16. 
Initiatives in Olsztyn (formerly the Provincial House of Culture). It left the stage on 30 November 2009 with the performance "To Name the Momentary Forever", thus closing its 52-year activity.

"The Silent Comedians" is the first book on its history and - as time has shown - a kind of epitaph.

Professor Bohdan Głuszczak died on 3 February 2016 at the age of 80, after a long illness.

\section{BIBLIOGRAPHY}

10 lat Olsztyńskiej Pantomimy Głuchych. Mówiący gestem [10 years of the Olsztyn Mime Ensemble of the Deaf. Speaking by Gesture] (catalogue), Department of Culture of the Presidium of the Provincial National Council in Olsztyn, Olsztyn 1967.

Berliner F., Polish Mime Ensemble of the Deaf "Show Business" of 21 August 1975.

Białostocki J., Dürer, „,Sztuka” Publishing House, Warszawa 1956.

Bohdan Głuszczak's statement in an interview with Tadeusz Prusiński - TP’s private archives.

Francisco Goya y Lucientes, "Caprichos”, cykl 80 rycin. Katalog wystawy z okazji 200-lecia urodzin artysty, 17 marzec - 17 kwiecien 1947 r. [Francisco Goya y Lucientes, "Caprichos," a series of 80 etchings. Catalogue of an exhibition on the 200th anniversary of the artist's birth, 17 March - 17 April 1947]. Muzeum Narodowe w Warszawie, 1947.

Głuszczak B., Wszystko powiedzieć nic nie mówiąc [To Say It All While Saying Nothing], „Scena", 1973, 4.

Głuszczak B., Wyjście z „polskiej otchtani” - rozmowa Bohdana Głuszczaka z Bohdanem Kurowskim [Getting Out of the "Polish abyss" - Bohdan Głuszczak's interview with Bohdan Kurowski], [in:] programme booklet for „The Polish Requiem”, choreodram in 10 images, Stefan Jaracz Theatre, Olsztyn 1978.

Keller I., Sztuka zatopiona w milczeniu [Art Plunged in Silence] “Teatr”, 1978, 12.

Program integracyjny "Być razem" ["To Be Together" integration programme], programme information booklet, Olsztyn 1996.

Prusiński T., Milczący komedianci. Rzecz o Bohdanie Gtuszczaku i Pantomimie Olsztyńskiej [The Silent Comedians. A Study on Bohdan Głuszczak and the Olsztyn Mime Ensemble], Miejska Biblioteka Publiczna w Olsztynie and Pracownia Wydawnicza ElSet, Olsztyn 2015.

Sokołowski M., Speaking by Gesture, “Film”, 1988, 4.

Z dziejów pantomimy, czyli pałac zaczarowany [From the History of Pantomime, or the Enchanted Palace], Państwowy Instytut Wydawniczy, Warszawa 1975. 